\title{
The Taliban and the Crisis of Afghanistan
}

\author{
Robert D. Crews and Amin Tarzi, eds.
}

Cambridge, MA: Harvard University Press, 2009. 430 pages.

The latest estimate by Afghan expert Gilles Dorronsoro (International Herald Tribune, 15 September 2010) states that no state structure remains in 80 percent of Afghanistan's districts, that the Taliban are rapidly filling the vacuum, that the NATO surge in the south has failed, and that the allies should negotiate a settlement with them in order to achieve what assurances they can about discouraging the presence of al-Qaeda before it is too late. This book explains why such a limited success is the likely outcome of NATO's attempt to build a working central Afghan state. It contains essays by ten 
leading scholars in the field who met at a conference in 2004. Most of the papers have been extended to a cut-off date of 2007.

The book sets out to answer several questions: Are the Taliban, usually considered a militantly traditionalist movement, in fact a new phenomenon in Afghan history? Are they no more than a foreign creation, an instrument of Pakistan's geopolitical interests in a post-cold war world? At the same time, given their utopian theology that looks back to an imagined period of early Islamic purity, should they be seen as essentially "medieval" and "antimodern"? Are these sufficient characterizations of this extraordinarily effective movement, or should more attention be paid to other factors, such as the long history of state-society relations in Afghanistan and how they have interacted with the great powers?

Robert Crews and Amin Tarzi introduce the essays by providing a substantial overview of the Taliban's rise. Abdul Kader Sinno writes that the Taliban were able to mobilize support not primarily because they were zealous Muslims, had strategic support from al-Qaeda and Pakistan, or had substantial resources to dispense, but because they were particularly skillful in their engagement with Pushtun politics. He finishes with the interesting idea that the Taliban may offer the last opportunity in history to observe the strategies that might be deployed to persuade tribal societies to unite in pursuit of a great object, as in the case of seventh-century Arabia or the Mongols of thirteenth-century Central Asia.

Neamotallah Nojumi is concerned, on the other hand, with emphasizing the linkages forged in the 1980s and early 1990s between the Afghan political parties based in Iran and Pakistan and the localized centers of antiSoviet resistance within Afghanistan. These ties linked the Islamist agendas of Afghanistan's neighbors to the relatively small number of Afghan Islamists, helping them to sideline other forms of leadership. Juan Cole, in a clever article, shows how the Taliban used "modern techniques of rule" from mass spectacle to surveillance, tanks and radio, both to challenge tribal custom and to redraw the boundaries between public and private. Here the regulation of gender roles, which so exercised public opinion in the West, was central.

Nazif Shahrani, in an important article, explains the value of the historical perspective. The Taliban are just the most recent episode in a series of Pushtun attempts to create a Pashtun-denominated Afghan state. If, in recent years, non-Pushtuns have been unwilling to accept Pushtun authority, it is because of the breakdown of centralized authority that flowed from the struggle against the Soviet occupation. Lutz Rzehak's fascinating essay draws on 
fieldwork in the southwestern province of Nimroz, where he examined oral tradition to demonstrate how the Baluch have remembered Taliban rule. In the process he illustrates how historical songs, now also transmitted through the mass media, celebrate the country's record of resistance to the invading nineteenth-century British, Soviets, and now the Americans.

Robert Canfield explores the emergence of new identities among the people of Afghanistan and its neighboring countries, noting how they have come to be linked to international Islamist networks and how Afghan Islamists no longer focus just on their own country; rather, they now link their fate to those of Palestine, Iraq, and elsewhere. Crews investigates how the first Taliban government, in the cause of state-building and winning international support, developed the concept of the "moderate Taliban" that, after their government fell in 2001, enabled numbers to reenter politics. Amin Tarzi examines what happened to these and other Taliban elites after 2001 and shows how they eventually coalesced as nodes of opposition to Hamid Karzai and his foreign backers. Atiq Sarwari and Robert Crews round matters off, demonstrating that the Karzai government, in part bolstered but in large part handicapped by its western supporters, has not only failed to provide a convincing political alternative for the country's peoples, but also, by 2007, was confronted by growing Taliban insurgencies. Karzai has failed to solve the country's enduring state-society problem, a failure that is even more glaring in 2010 .

This excellent collection of essays should be read by everyone concerned with Afghanistan's recent past, present, and future. They emphasize the importance of avoiding lazy thinking and looking behind labels to see what social forces are really at work; reveal that the Taliban are just the latest episode in the competition between Pushtuns and non-Pushtuns for control of the Afghan state; and demonstrate that the prime actors are indigenous but, as before, have engaged with outside forces to attain their ends. Moreover, in the process they use a wide range of "modern" tools and techniques. So the current Afghan imbroglio has deep roots in the past. What is new is the globalized context, with the fear of terror and of Islam on the one side, and an Islam-wide hatred of western bullying on the other.

Francis Robinson (F.Robinson@rhul.ac.uk) Sultan of Oman Fellow, Oxford Centre for Islamic Studies Professor of the History of South Asia, Royal Holloway University of London, United Kingdom 